\title{
The institutional space of community initiatives for renewable energy: a comparative case study of the Netherlands, Germany and Denmark
}

\author{
Marieke Oteman*, Mark Wiering and Jan-Kees Helderman
}

\begin{abstract}
Background: Community initiatives for renewable energy are emerging across Europe but with varying numbers, success rates and strategies. A literature overview identifies structural, strategic and biophysical conditions for community success. Our analysis focuses on institutional structure, as we describe the variety between the Netherlands, Germany and Denmark, and place this within the institutional context of the policies, power structures and energy discourses of each country.
\end{abstract}

Methods: We conducted a policy arrangements analysis with a series of semi-structured interviews, extensive content analysis of policy documents, media analysis and use of existing research, in a qualitative comparative analysis between the Netherlands, Germany and Denmark.

Results: We demonstrate that the (evolving) institutional configuration of the energy sector strongly influences the available space for community initiative development. Denmark has a traditionally civil society-friendly energy sector, although opportunities for communities have decreased following the scaling up of production facilities. The Netherlands knows a predominantly market-oriented institutional arrangement that leaves little space for communities, but the potential for community based energy is increasingly recognized. In Germany, the typically state-dominant Energiewende strategy creates a window of opportunity for community initiatives that fit within the state policy.

Conclusions: We conclude that the institutional arrangement of the energy policy subsystem can both constrain or enable community energy projects. Decentralization appears to be one of the most important characteristics of the general institutional development and generally increases the institutional space for local (community) players. The alignment of discourses across government levels and actors is one of the important enabling features of an energy system, as it provides the stability and predictability of the system that enables communities to engage in renewable energy projects.

Keywords: Community initiatives; Renewable energy; Institutional arrangements; Institutional space; Policy analysis

\section{Background}

The transition from fossil fuels to renewable energy presents one of the biggest current challenges for European governments. All across Europe, governments are seeking to meet the goals of the EU climate and energy package [1] to which they have committed themselves, while their economies and industries are still largely dependent on fossil fuels. Both states and markets are constrained by the

\footnotetext{
* Correspondence: m.oteman@fm.ru.nl

Institute for Management Research, Nijmegen School of Management, Radboud University, Nijmegen, P.O. Box 9108, Nijmegen 6500, HK, the Netherlands
}

infrastructural and economic path dependency of large fossil energy systems. No wonder then that citizens, organized in communities, have taken initiative by themselves to innovate their energy provision in a more sustainable way. Community initiatives for renewable energy are on the rise. There are thousands of cooperatives and other local, non-profit initiatives active across Europe, aiming to promote the production and consumption of renewable energy (RE) and reduce energy consumption [2]. These civil society activities for renewable energy and for sustainability in general have received an increasing amount of political and media attention [3,4]. Community-

\section{苗 Springer}


based implementation of (alternative) RE technologies has widely been advocated as 'a way of implementing renewable energy technologies, emphasizing themes of self-sufficiency, local determination, engagement and empowerment' [5].

Although there is a large variety among communitybased RE initiatives, what they have in common is that they are typically locally based, non-commercial, smallsized and that they rely to a large extent on the engagement and actions of highly motivated people with limited power and limited resources [6]. It is probably because of these characteristics that studies of communitarian RE initiatives have a tendency to overstress the importance of agency characteristics such as leadership, while neglecting the importance of contextual and structural factors. Yet, the rules and procedures for project planning and implementation, available subsidies and the attitude of market and government partners may also be critical success factors for community projects.

This paper studies the influence of these contextual and structural factors. Starting from the observation that community initiatives vary in occurrence and variety across countries, we ask in what ways the institutional configuration of the energy sector facilitates or constrains community initiatives for renewable energy. Since we are interested in the prospects of community RE initiatives, it is important to understand how and to what extent in current policy arrangements, the state, market and associations are complementary to community RE initiatives and to what extent they compete with, adopt or take over those initiatives. By identifying the prospects of community initiatives and their institutional opportunities and constraints, it becomes clear under which institutional conditions communities can be a partner for governments in their search to make the shift from fossil fuels to renewable energy.

The paper is structured as follows. First, we provide a literature review on theoretical explanations for community initiatives' presence and success, divided into agencyoriented, structure-oriented and biophysical perspectives. We elaborate on the structure oriented approach by introducing institutional arrangements theory, in order to classify the different institutional configurations in which initiatives are situated. Next, the 'Results and discussion' section contains an account for the methodology, including the case selection and data collection. The section 'Conclusions' presents data from the case study countries Denmark, Germany and the Netherlands. We end this paper with conclusions and a reflection on the prospects for community-based RE initiatives.

\section{Community initiatives for renewable energy}

Community initiatives for renewable energy can be defined as decentralized, non-governmental initiatives of local communities and citizens to promote the production and consumption of renewable energy. They form a heterogeneous group of projects focused at the provision or production of $\mathrm{RE}$, the reduction of energy consumption and the support for private households to produce their own RE or reduce private consumption. Following Walker and Devine-Wright [7], RE projects can be categorized as community projects by distinguishing the target group of the project (who the project is for) and the actively involved participants (who the project is by). Projects are characterized as community initiatives when the local community participates actively in the planning, decision-making and/or exploitation of the project and benefits from its revenues or other accomplishments [8]. Community initiatives for renewable energy are only those initiatives that are involved in the production or provision of renewable energy or aim to achieve this in the near future. This excludes a large variety of broader sustainability initiatives.

Theoretical explanations about the occurrence and opportunities for community initiatives take either an agency-oriented focus or a structure-oriented focus, and most acknowledge the importance of (bio)physical characteristics. Agency-oriented explanations tend to look at the incidental characteristics of individual projects. Community initiatives depend largely on unique individual features such as detailed local knowledge, intrinsic motivation, and leadership capabilities. While these individual factors may explain variation between projects, they cannot explain why different countries display different patterns of appearance and success of community initiatives. Structure-oriented explanations, on the other hand, focus on the institutional contexts in which community projects are embedded. This ranges from local institutionalized structures to the meso- and macro-level of whole policy subsystems and country characteristics such as the formal legislation and the degree of centralization. Each of these approaches tend to identify different success and fail factors for community RE initiatives, which will be outlined below. Biophysical characteristics form the preconditions for projects, as they set the boundaries for what is physically possible and feasible.

\section{Agency approaches}

Community projects are typically small and are to a large extent dependent on the individual motivations and capacities of their members. A literature review points out a number of individual characteristics, sometimes supplemented by (local) structural features. Middlemiss and Parrish [6] distinguish between cultural, organizational, infrastructural and personal capacities of grassroots initiatives and other agency-oriented explanations fit well into this taxonomy. Cultural capacity includes the legitimacy and socially defined meaning of sustainability objectives, 
as well as their embedment in community values. A proenvironmental attitude and the intrinsic motivation to act according to environmental/sustainability beliefs has been a precondition for a success in the past [9]. Citizens can be intrinsically motivated to improve their (direct) environment, which means that economically unviable projects might still be carried out, but economic interests are becoming increasingly important motivations as well (personal communications EnergiByen Frederikshavn, 2013). The individual motivations for $\mathrm{RE}$ engagement can be diverse and can supplement each other pragmatically. Hence, social movements for local RE may be based on arguments of autarky, anti-capitalism and energy security, as well as anti-nuclear sentiments $[10,11]$. These motivations can supplement environmental motivations, and the increased economic viability of projects due to technological developments and subsidy schemes adds an economic motivation. The monopoly of fossil fuels, technology and financial means rested with large companies and foreign countries, and local RE provides energy security, control over production and supplies and the reduction of the risk of shortage and accidents [12].

Organizational capacity refers to the position of community RE initiatives within the wider local community. Community initiatives for $\mathrm{RE}$ are advocated because they emphasize self-sufficiency, local determination, engagement, social cohesion and empowerment of local communities [5]. Social support of the wider community for community projects (either environmental or economic) positively influences their success [9], as does social cohesion in general. When successful, community involvement creates a sense of ownership and responsibility that reduces not in my back-yard (NIMBY)effects and increases local acceptance of wind parks or other RE installations [13]. A community also needs social capital and social cohesion to be able to organize community projects [14], as well as political will [15].

Infrastructural capacity pertains to grid access and the provision of facilities for sustainability by the government or market parties. However, this is still discussed at the local level. Local communities can act as a fertile testing ground for new technologies, which stimulates innovation and provides highly visible examples of 'technology at work' [15]. Lastly, personal capacity refers to the resources of the individual members of an initiative. Community projects typically rely on the voluntary contributions, intrinsic motivations, and collective action capacities of their members. This includes their skills, knowledge, leadership qualities, values and enthusiasm [6]. Knowledge and (access to) technology and expertise are also seen as critical conditions for small projects [15], as is the availability of budget (ibid.). These different capacities act as indicators for the strength of a community initiative.

\section{Structure approaches}

The literature on community RE identifies a number of macro- and meso-level institutional conditions that can enable or constrain community initiatives and thus determine their institutional space. Schut et al. [16] state that 'space for innovation is embedded in and constituted by dynamics between socio-cultural, biophysical, economic, political and legal subsystems'. Socio-cultural attributes include the public perception of energy and of the role of communities in this and the attitude towards experimenting and innovation. Economic conditions include not only the division and allocation of financial and other material resources among the actors in the energy sector but also the general economic (investment) climate. This depends partly on the expected profitability of the project. Without access to financial resources from other partners, community initiatives will be limited in their options. Next, legal conditions include not only the formal legislation that directly and indirectly regards $\mathrm{RE}$, including Electricity Acts and grid access, but also the degree of territorial and functional decentralization, the structure of the polity and the procedures for collective decision-making. Political factors are not only related to the legal framework but also include the 'softer' characteristics of the political system such as subsidy and schemes and the political will to enable RE projects.

\section{(Bio)physical conditions}

Lastly, physical conditions form boundaries on the physical possibilities of projects. They include not only, e.g. the availability of renewable resources such as sunlight hours and wind potential (biophysical) but also the options for harvesting resources, such as availability of technologies. Moreover, the spatial planning of the project area is an important physical condition. Urbanized regions will be less suitable for large-scale plans, as physical space is limited, contested over, and expensive. Likewise, the remoteness of rural regions might present problems for (grid) infrastructure. Beyond practical problems, the spatial layout and degree of urbanization also influence local structural and agency characteristics. Governance structures, e.g. tend to be more complex in cities, where the multiplicity of actors and interests increases, as well as the variety of scales of governance and political spaces [17]. For successful project implementation, plans should be aligned with the biophysical and built environment of the project, which poses specific demands on the spatial planning and planning processes. Furthermore, the degree of urbanization influences the preferences for RE developments and the readiness to take local action [18].

Table 1 summarizes the factors and characteristics that are assumed to be important for the success or failure of community RE initiatives. 
Table 1 Characteristics that influence occurrence and success of community RE initiatives

\begin{tabular}{lll}
\hline Type & Dimension & Characteristics \\
\hline Strategic & Cultural & Legitimacy of sustainability objectives, pro-environmental attitude, willingness to act \\
& Organizational & Support for community action \\
& Personal & Leadership, knowledge and expertise, access to technology and grid, adaptive capacity, management skills \\
Institutional & Political & Subsidies, flexibility, priority for sustainability goals, project support (advice, financial), network \\
& Legal & Formal rules and regulations, decision-making procedures, degree of discretionary space, control mechanisms \\
& Economic & Division of material resources, availability of investors, expected profitability \\
& Socio-cultural & Capacity for institutional learning, problem perception, attitude on experimentation \\
& & Wind speed, solar hours, tidal waves, hydropower; presence of fossil fuels, urbanization, technological developments
\end{tabular}

\section{Institutional arrangements theory}

It goes without saying that both individual - agency-based factors and structural factors are important in explaining the success or failure of local community RE initiatives, within the boundaries set by (bio)physical conditions. By introducing institutional arrangements theory, we research the relative importance of structural characteristics of the energy sector.

Hall and Taylor [19] define an institutional arrangement as 'the formal or informal procedures, routines, norms and conventions embedded in the organizational structure of the polity or political economy'. Following Sabatier and Jenkins [20] and Howlett and Ramesh [21], the set of policy institutions can be considered a policy subsystem, as a 'space' where relevant actors discuss policy issues and persuade and bargain in pursuit of their interests. It includes actors who are intimately involved in the issues at stake, as well as those who are only marginally involved. Policy subsystems incorporate both interest networks and discourse communities. Subsystems may be constituted by an almost infinite variety of actors and institutions, and their composition may vary by country, by policy sectors or domains and over time.

Even within one country, many of the mentioned factors are shaped at multiple levels of governance, providing a specific institutional local landscape for each community project within the energy sector. In this paper, we distinguish between four such ideal typical ordering principles that can be identified by their central institution and their guiding principles [22] and finds its roots in the classical divide between market, state and society. A market-oriented system is guided by the principle of dispersed competition and has for-profit market players as its most influential actors. A state or bureaucratic system is guided by hierarchical control with the government as dominant actor. A civil society or community-oriented system will be based on spontaneous solidarity. Fourth, a corporatist associational order will be governed through an institutionalized and organized associational structure [23].

Governance of the energy sector can be considered a mixture of these four institutional logics that form a set of interrelated incentives and constraints, which are likely to influence agent's behaviour and strategies. The prospects of community RE initiatives are dependent on the way these four different logics relate to each other in the energy sector and to what extent the state, market and associations are complementary to community RE initiatives and offer them institutional space. Institutional space is here defined as the degree of discretionary freedom of community initiatives to decide autonomously about the design of a project (in terms of procedures and planning) and its contents (in terms of its goals and means). This includes not only the absence of constraints but also the presence of enabling conditions. In the case of community renewables, this means that the interplay of state, market parties, possible associations and communities themselves and their guiding principles - offers a certain room for communities to create their own renewable energy provision. This hypothetically influences the success that these projects will have as well as their spread and heterogeneity.

\section{A community-oriented ideal type}

It seems obvious that the institutional space for communities would be the largest in a community-oriented idealtypical model of governance. However, since the capacities and ambitions of community projects usually remain at a local scale, the arrangement as a whole and the network of community and other stakeholders have to provide an enabling environment for small-scale initiatives to develop. Even when an arrangement is community-oriented, communities are always embedded in a subsystem with economic and political players. In Western-European liberal democratic countries, there always is a fundamental imbalance of power between civil communities, the (local) government - who hold formal decision-making power and political legitimacy as well as some of the resources (e.g. the electricity grid) - and the markets that hold part of the resources, technologies, expertise and financial resources. Therefore, communities, government, market parties or associations will somehow cooperate to enable societal initiatives to develop. Given these conditions, 
however, the community-oriented ideal-type model of governance is indeed most promising. It leaves room for decentralized policy and local variation tailored to specific circumstances, preferences or dominant ideas within the community. Nonetheless, the question remains if communities themselves have the capacities to develop in such an 'open' environment, in which there is much less steering than, e.g. the government-oriented arrangement. In the latter, communities might have less space but more direction, which might lead to success as well.

\section{A state-oriented ideal type}

A system dominated by state hierarchy can both enable and constrain communities. State steering increases the chances of success for certain types of community initiatives, namely, those that are institutionally supported through, e.g. funding, tenders or permission grants. At the same time, hierarchical control can limit the space of other community initiatives, which implies that there will be a low variety of initiatives. Only those that are institutionally supported are likely to succeed, and other initiatives will have no space to develop. This decreases the chances for, e.g. new technologies or experimental designs, because they are unlikely to fit into the institutional structure of rules and finance of the state. Another hypothesized limitation to this type of basic institution or model of governance is that the space provided to communities by the state has to overlap with the needs and possibilities that appeal to the communities. Subsidy schemes can for example stimulate a certain activity, such as purchasing solar panels, but for a community that strongly values the authentic looks of its buildings for tourism, this hypothetical institutional space cannot be used.

\section{A market-oriented ideal type}

A market-oriented system has an economic incentive that is tailored towards preferably larger market parties (economics of scale) and therefore leaves little room for projects that are non-profit or small-scale. Moreover, this ordering principle generally lacks uniformity in rules and policies at the decentralized level because the national government will turn mostly to national schemes for large investors to create renewable energy. This means that subsidies, knowledge and detailed policy are most likely to be found at the national level and not locally. Community initiatives therefore face a larger challenge to acquire the necessary resources and knowledge about relevant rules, rights and options, which poses a major constraint. Also, in a market-oriented system, the weight attributed to profit is larger, and because profits of community projects can be expected to be low, this decreases the chances of success. This is both because the projects would be less interesting to investors, which would weaken the network of a community initiative, and because the market-oriented discourse might leave less room for non-profit considerations in the communities in general.

\section{A fourth order? The associational ideal type}

Lastly, the corporatist associational order is clearly visible in, for example, the field of agriculture (corporative structures forming a green front) or in housing policies with housing associations. This order is not straightforwardly recognized in the subsystem of renewable energy. This would actually be a new hybrid institution in which societal roots of shared responsibility and environmental concerns are combined with market tasks such as energy profitability, security and access and governmental responsibilities (both environmental and economic). In the energy sector, this would provide for a (hybrid) setting in which institutions are originally stemming from community initiatives but are highly institutionalized into formal decision-making, for example, through semigovernmental associations that take over parts of the energy market. Even though at present, the associational order does not appear dominant, elements of this idealtype might be visible and/or emerging in the energy sector. The call for devolution of functions to local groups and associations and a new role of the state as defining the basic goals of public policy and selecting the social actors that participate in the formation and implementation of public policy or services [24] are clearly present in the normative arguments for facilitating and formalizing community initiatives and participation. The associational order does not only have to resemble a full corporatist system but could also indicate a more general turn towards a system in which state and civil society become part of a single, regulatory framework that reveals new modes of cooperation (ibid.). This could, e.g. include public private partnerships, civic participation in local planning or a large degree of organization of the community movement.

\section{Methods}

Our theoretical assumptions started from the ideal types of ordering principles [22] that we have rephrased models of governance. To describe the empirical 'on the ground' configurations, we used the policy arrangements approach (PAA) $[25,26]$. This approach offers a comprehensive method to describe policy subsystems, as will be elaborated upon in the following paragraphs.

\section{Case selection}

Empirically, we conducted a comparative analysis of community initiative movements in the Netherlands, Germany and Denmark. Denmark was chosen because of its wellknown reputation for creating an enabling environment for community initiatives and collective action, which 
resembles the community-oriented ideal type [27]. The Netherlands was chosen because of its traditionally strong ties with the (predominantly fossil fuel oriented) energy industry and its market-oriented approach; while Germany, finally, is known for the dominant intervening role of the state in the energy system and its system of public RE provision. This approaches the state-oriented ideal type. Using this variety on the independent variable, we hope to explain the position of community initiatives in each country through their institutional arrangement and which ideal type this relates to.

\section{The policy arrangements approach}

The PAA starts from the assumption that policies and polity, such as the ones guiding the energy sector, can be described as a policy subsystem in which specific patterns of behaviours of actors, power relations and divisions of resources as well as rules of the game and discourses are - throughout the years - institutionalized into a specific arrangement. Such an arrangement not only shows a certain degree of institutional stability but is also open to changes from outside (because of societal modernization, changing technology, changing modes of governance on higher levels of the political system, the role of Europe, etc.) or internal imbalances (e.g. actor conflicts, diverging discourses vis-à-vis actor - coalitions, outdated rules of the game or changing power relations). A PAA has been defined as the 'temporary stabilization of the content and organization of a policy field' [28]. PAA distinguishes between four dimensions of a policy subsystem: actors and coalitions, power and resources, rules of the game and policy discourses. By including discourse (ideas) as a relevant dimension of a policy framework, PAA can be placed within the discursiveinstitutionalist tradition. Through mapping the actors, their constellations and coalitions and relative power positions, one can see the interaction of the main 'players of the game'. The rules of the game, both formal and informal, also include the procedures that have to be followed and the political culture. Resources include not only financial resources but also power relations and political influence. Lastly, discourse includes the framing of policies, RE and energy problems and dominant paradigms. Using the PAA will lead to an overview of the institutional arrangement, the place of community initiatives and the cultural and organizational capacity of the Middlemiss and Parrish typology. The relevant characteristics that were identified in Table 1 will also fall into place. Political and legal institutional characteristics are part of the power division between the actors, the rules of the game which they establish and the allocation and division of resources. Similarly, resource division is present in the economic dimension. The socio-cultural characteristics of the subsystem reflect its discourse on RE. These factors are intertwined and mutually influencing as is demonstrated in the case description.

\section{Data collection}

To construct the descriptions of the current presence of community initiatives and the policy arrangements of the energy sector, a large variety of data was used. This includes a content analysis of all relevant national legislation since the liberalization of the energy market in the three countries, such as Electricity Acts, Energy Agreements, and the Danish Renewable Energy Act [29]. The content analysis also included a variety of provincial/state level legislation, subsidy and grant schemes, tenders and procedures for planning and permits.

As a second strategy, we conducted over 20 semistructured interviews in Denmark and in the Netherlands and a small number in Germany, with (umbrella) organizations, academic experts, energy companies, research and development (R\&D) institutes and politicians. This gave insight in the energy policy subsystem and the position and activities of community initiatives.

We supplemented this with data from a media review using the archives of large national newspapers. This was not a full-fledged media analysis but a secondary source of data to supplement the content analysis [30]. This search added information on community initiatives and RE policy debates. Additionally, there is also a large availability of data that we used from umbrella organizations [31,32], previous academic research, civil society movements and governmental organizations. This includes databases of projects [33] and case studies on renewable energy policy and community projects. We conducted site visits of commercial, community-based and local government-owned projects in the three countries to gain insight into their daily affairs. We conducted participatory observation at meetings of umbrella organizations and sustainability networks, expert conferences and information meetings about RE.

The study has included a large variety of data, of which the content analysis of policy documents, the interviews and the used databases account for the majority of the findings. This triangulation enhances the validity of the findings, mostly for the Netherlands and Denmark, since for Germany, fewer interviews could be conducted. To supplement this data for Germany, we refer to case studies on wind power and renewable energy policy in Germany [34-40] and documentation on the Energiewende by nongovernmental organization (NGO)'s and researchers [41,42]. The partial reliance on data that was provided by other researchers and institutes reduces the reliability of the analysis, which is a constraint on the strength of the conclusions. However, the variety of used data is large, and the findings for each case are consistent across data sources. 


\section{Results and discussion}

Community initiatives for renewable energy are not a new phenomenon: in the Netherlands, wind cooperatives have been active since the 1980s [43]; in Germany, these even date back a century [44]; and Denmark has a rich history of both community-based district heating systems and wind cooperatives following the 1970s oil crisis [27] (personal communications Danish Energy Agency, 2013). This section describes community initiatives in each country and a sketch of the historical context and present configuration of the energy sector.

\section{Community initiatives in the Netherlands}

In the Netherlands, we can distinguish two different types of initiatives. The first type is the classical wind cooperative, in which members collectively own and exploit one or more wind turbines. Twenty-five wind cooperatives were founded in the late 1980s and early 1990s, emerging from the anti-nuclear and pro-environmental movements [43]. These cooperatives still exist (although a few merged), and a small number of new cooperatives were established in the past two decades. Although some are involved in other activities besides exploiting the turbine(s), such as providing information about other renewable energy or sustainability practices (e.g. home insolation), they are focused, well-established organizations. Since net metering is prohibited, it is financially unprofitable for cooperatives to collectively exploit facilities for self-delivery to members. Collectively owned facilities usually sell their electricity on the market to large RE suppliers such as GreenChoice and Eneco (personal communications WDE, 2013; personal communications Eneco, 2011). Out of the 31 currently active wind cooperatives, only two sell directly to their members (Zeeuwind and De Windvogel). The wind cooperatives are found in rural areas and have a regional identity.

The second type of initiatives is of more recent date: the past few years have known a drastic rise in the number of 'new style' community initiatives for decentralized renewable energy, often referred to as local renewable energy companies (LDEB). Apart from the traditional wind cooperatives, there are over 200 local initiatives involved in RE, including over 55 registered cooperatives and 15 more cooperatives that are in the process of legal registration [32] (personal communications Van Bekkum, 2013). Furthermore, there are well over 100 associations, foundations, informal working groups and project teams working on local RE. These initiatives aim to promote energy savings, promote private $\mathrm{RE}$ production, facilitate cooperative $\mathrm{RE}$ production, and/or supply RE to their members. The initiatives have a different spatial distribution: where wind cooperatives are found in rural areas, mostly near the shores; LDEBs are found in cities and rural areas alike. They often have a city or municipal identity, which is reflected in their names.
Most LDEBs were founded recently and are therefore still in their planning phase. Their activities firstly focus on the internal organization and the development of a sound business plan. Production of RE is not implemented yet for most LDEBs, but there is a wide range of plans, ranging from putting solar panels on public roofs (e.g. AZEC in Doetinchem) to manure fermenting (e.g. Haarlose Marke). Most projects are starting with the 'low hanging fruits': relatively cheap activities such as information spreading and collective purchase of low energy lighting, solar panels or home insulation measures. Another activity that is typical for the Dutch situation is the purchase of 'green electricity' through collective contracts with large energy providers such as GreenChoice. Although this is a way of providing green electricity to members, the only decentralized aspect of it is the local collective discount with large, centralized and for-profit energy companies.

The main motivation for LDEB's is both environmental and economic: to provide a better (local) environment and a sustainable future and create local economic benefits through energy savings and revenue from joint projects. The initiatives sometimes receive a financial contribution from the municipality, but this is not standard. They rely on local fundraising for their starting capital, which explains the trend to start with small activities.

Overall, the Dutch community initiatives are relatively new, with the exception of the traditional wind cooperatives. The recent large growth of initiatives has resulted in a heterogeneous group of early-phase projects that are still exploring their options for local RE production and provisions.

\section{The Dutch institutional arrangement}

The dominant governmental actor in the Dutch energy sector is the national Ministry of Economic Affairs, working together with the provinces, the facilitating state-based agency Agentschap NL, the Environmental Assessment Agency (PBL) and the Social and Economic Council (Sociaal Economische Raad, SER) [45]. The prominence of the Ministry of Economic Affairs and the SER creates a strongly economical approach to renewable energy planning (ibid.). The government subsidizes RE through the Stimuleringsregeling Duurzame Energie (SDE+) subsidy for purchase of private solar panels and by compensating wind turbine exploiters for net losses (e.g. 150 million euros in 2011) [46]. The national government set a goal of $14 \%$ RE by 2020 (which is very modest compared to EU targets and other EU countries). To reach this goal, it looks primarily at large business partners rather than at communities (personal communications PBL, 2013; SER working conference Energy Agreement, 2013). Although the policy making is centralized, provinces and municipalities have the freedom to implement their own strategies 
and plans. They display a wide variety of approaches to $\mathrm{RE}$, from prohibiting projects (e.g. the building stop for turbines in Noord-Holland province) to actively founding them or aiming for a climate-neutral city (e.g. Nijmegen). Some provinces, such as Gelderland, are actively monitoring and encouraging and even subsidizing local projects, but this depends on the province (personal communications Gelderland Province, 2013). There are many municipal subsidies for, e.g. home insulation and joint purchase of solar panels [47].

Next to government actors, the market parties have a large role in the arrangement, and they are mostly fossil fuel-oriented. The Gasunie has a strong lobby, as do Royal Dutch Shell and Exxon. Large fossil fuel-based companies that operate in the Netherlands are sometimes indicated as the 'coal lobby' and include Eon, Nuon/Vattenfall, Essent/RWE and Electrabel/GDF Suez. The fossil fuel industry has invested over 5 billion euros in the past years in three new coal-fired power plants in Slochteren and De Tweede Maasvlakte, which means they have a large interest in low coal prices and the absence of strict emissions trading [48]. Historically, the Netherlands also has large interests in the domestic gas industry, with gas revenues of 14 billion euros in 2012 [49], and in the fossil fuel dependent heavy industry. The Dutch government stated in 2008 that it facilitates the energy industry and that market parties, through investing in production facilities and (international) trade, determine the energy mix (ibid.). Not only the companies that have electricity or gas as their products lobby for fossil fuels. Sectors such as agriculture and transport are heavily subsidized for their use of fossil fuels and hence form a strong lobby as well. The tax schemes for kerosene and agricultural diesel and the energy tax reduction for bulk consumers of energy are only a few examples of the 50+ energy interventions of the Dutch government that favour fossil fuels [50]. In comparison to the vested interests of the fossil fuel (dependent) industry, the influence of market parties that lobby for RE is very little. RE suppliers in the Netherlands mostly have a mixed portfolio with both RE and fossil fuel-based energy and import most of their RE through certificate trading (personal communications Eneco, 2011). There is no large industry for building RE facilities (such as the solar panel industry in Germany or turbine manufacturing in Denmark) and although a few NGOs for RE exist, mostly in the shape of umbrella organizations for local RE initiatives, they have relatively little political influence or financial means (personal communications HIER Opgewekt, 2013).

The 'rules of the game' in the Netherlands have been altered since the 2010 parliamentary elections, when new policy goals and means were introduced and energy policy was allocated to the department of Economic Affairs. Prior to the elections, there was an extensive interdepartmental cooperation, and energy policy was linked to climate change and environmental issues [45]. However, recent policies have again become more economic-oriented, focusing on 'high potential' projects through the Green Deal subsidy system that rewards projects that are economically viable. The SDE + subsidy scheme for solar panels on private households was capped. The primacy of the department of Economic Affairs means that policies are more aimed at achieving energy security and the international competitive position of the Netherlands (personal communications PBL, 2013).

There are relatively little investments in nuclear power. At present, there is one active nuclear power plant (Borssele) and there were plans for a 'Borssele 2', but these plans were abandoned by prime investor Delta Energy in 2012. As stated by the investor, this decision was based on NIMBY protest, overcapacity of the Dutch grid following the economic crisis and fossil fuel-based plants in Groningen province, the negative image of nuclear power after Fukushima and uncertainty about Dutch policies on $\mathrm{CO}_{2}$ emissions trading [51]. With the nuclear alternative abandoned, the Dutch government turned to large wind projects (both offshore and onshore) to reach its sustainability targets, which were reduced from $20 \%$ to $14 \%$ RE by 2020 . The government takes a centralized, economic approach towards large-scale wind farms, but planning is partly left to the provinces that have each been given a minimum target for installed wind capacity (but without real sanctions). Each province takes its own approach, e.g. Limburg has a minimum of three turbines per site, whereas Noord-Holland stopped all wind park developments.

Overall, the RE subsystem in the Netherlands can be categorized as a vested interests and business-oriented policy arrangement. Market parties are dominant in terms of steering the energy mix and taking initiative for new energy facilities, although the government does set minimum requirements for $\mathrm{RE}$ production and consumption and the upcoming Energy Agreement promises a more active and steering role for the government for RE production. At the moment, however, policies are framed in terms of cost-benefit analyses, risk avoidance rather than innovation and the (international) economic position of the country in energy supply and trade. Sustainability or climate change are no big issues and hardly part of the dominant policy discourses. There is an increase of domestic RE production, through household efforts, business investments and large wind parks. The role of local communities has long been limited to strong local NIMBY responses. With the exception of the preparations for a new Energy Agreement in which the government will set out its new strategy to comply with the European 2020 targets, renewable energy does not seem to be very high on the political or public agenda. 
Community initiatives in the Netherlands can thus be characterized as a very young phenomenon, which is rapidly developing but has a small influence and receives little attention from the dominant government and market players. Community initiatives are limitedly institutionally supported through rules, subsidies or active governmental support.

\section{Community initiatives in Germany}

Germany knows a large variety of community initiatives for RE, mostly set up as cooperatives (Energiegenossenschaften) $[41,52]$. The tradition of energy cooperatives dates back to the early twentieth century when decentral cooperatives (based on fossil fuels) were set up to assure electricity provision in remote areas $[44,53]$. Since then, the Energiegenossenschaften have been present in the German energy system, as has a network of municipal Stadtwerke: local utility companies that provide heat and electricity. These were originally owned by municipalities but are now often (partly) privatized or owned through local cooperatives. Since 2009, their number has risen drastically and they have become increasingly interested in local 'green' solutions for energy [34]. There are now over 650 Stadtwerke, which mostly have their own production facilities or are in the process of construction [44]. This covers a wide variety of projects including PV systems on public roofs, biomass-based heating and manure fermenting. They provide an example of citizen involvement and collaboration between citizens and local governments.

The largest group of cooperatives is formed by solar cooperatives, in strong contrast to the Netherlands and Denmark where these are virtually absent. Solar cooperatives are a relatively new phenomenon in Germany, and their number has risen greatly in the past years: from only 4 in 2007 to over 200 by 2010 [54]. Wind cooperatives (Bürgerwindparks) form a smaller group but with a longer history and larger installed capacity. They were founded from the early 1990 s onwards, enabled by the 1991 feed-in legislation [55]. There are now 45 wind cooperatives operational or under development [56], but wind parks also adopt other ownership models than the traditional cooperative [36]. It is estimated that over $50 \%$ of Germany's installed capacity of onshore wind was owned by private citizens and local initiatives in 2010 $[41,57]$. This is the same if other RE sources are included: about half of the RE production facilities are locally owned by private households and cooperatives (40\%) and farmers (10\%) [58,59]. This will however decrease if large commercial offshore wind projects are developed, as investments in that area have been negligible in the past years [41]. The produced electricity is sold to the grid, although there are increasing investments in private storage [51].
There is a large variety of RE sources and participation models used among community initiatives in Germany [34,36], but the PV cooperatives and Bürgerwindparks are the most successful and prominent [41]. The other initiatives know a large variety, including biomass heating, combined and heat power $(\mathrm{CHP})$ projects, and initiatives in early planning phase. We find projects in both rural and urban areas but with an increased attention for sustainability in cities.

\section{The German institutional arrangement}

The Germans are known for their 'Energiewende', the transition from a fossil fuel and nuclear power-oriented energy sector towards a more sustainable system with a large RE component. The Energiewende was initiated in the early 1980s because of growing environmental and climate concerns, and the 1989 Chernobyl disaster acted as a catalyst. Hence, the policies show a strong coupling between energy, climate change and environmental protection as well as anti-nuclear sentiments and safety concerns. The term Energiewende not only signifies the shift from fossil to RE but also a reorientation in policy making. The attention shifted from supply to demand (demand side management) and the planning process of RE production became more decentralized and more democratic (although overall targets have been decided top-down and the state adopted a dominant steering role). The traditional power division in which a few large energy companies dominated the market was altered through governmental steering and decentrally owned and exploited Stadtwerke and other RE facilities. Current German RE targets include 35\% of RE production by 2020 and large cuts in consumption. In the first half of 2012, Germany produced a record high $26 \%$ of its energy production from renewable sources. The RE component in the energy mix consists mainly of wind (9.2\%), biomass (5.7\%) and solar power (5.2\%) [60].

The actors in the energy production subsystem consist of multiple government levels, large market parties and an abundance of small, locally owned RE facilities. The 'big four' market parties that own over $80 \%$ of fossil fuel and nuclear-based energy production facilities in Germany are Eon, EnBW, RWE and Vattenfall [59]. As large industrial players, they lead a strong lobby for fossil fuels and nuclear power. Their share (and thus interest) in RE production facilities is very limited: only $6.5 \%$ of the RE facilities exploited in Germany is owned by the 'big four', whereas, as mentioned earlier, 40\% is owned by private households or cooperatives and another $10 \%$ by farmers (ibid.) [36]. This strengthens the public opinion that favors $\mathrm{RE}$ over fossil fuels because RE projects create revenue for villages or private owners and because of the growing safety concerns about nuclear power exploitation. The nuclear lobby has traditionally had a lot 
of power in Germany. In 2010, a national long-term strategy for the Energiewende was designed, in which nuclear power was seen as a 'transition tool': a choice that has been attributed to the influence of the nuclear power lobby. However, this was abandoned after the 2011 Fukushima disaster and subsequent strong anti-nuclear protests throughout Germany [61]. Public opinion proved stronger than the nuclear lobby, and Chancellor Merkel designed a new RE policy scheme in which nuclear power will be phased out to be abandoned completely by 2022 . This will be replaced by electricity from renewable sources, natural gas turbines, a decrease in consumption and demand side management [42].

In order to achieve these ambitious policy goals, a number of rules, stimulating and regulating policy measures, were put in place [37]. The Renewable Energy Act guarantees feed-in tariffs (FIT) with set rates for 20 years, to ensure profitability of each RE technology. It also regulates priority grid access for electricity from renewable sources. Moreover, the German state-owned bank KfW has 100 billion euros in credit loans available in 2012 to 2017, for RE production plans and energysaving projects such as building insulation. Financial support for RE is not new to German policy makers: in the late 1980s, three German towns introduced a fullcost compensation for solar PV utilities, which can be seen as the first decentralized prototype for FIT [42]. In addition, Germany has an environmental taxation scheme for environmentally unfriendly activities, such as use of fossil fuels. Subsidies for RE include a subsidy scheme for renewable heating in building renovations through the Renewable Heat Act and numerous state subsidies for private household energy savings and local production.

The decision to phase out nuclear power caused a sudden policy change, when 8 out of the 17 operating nuclear plants were shut down after the 2011 Fukushima disaster. Although the previous Schröder government had already designed the phase out, Chancellor Merkel had delayed these plans by 12 years and now changed her opinion on nuclear power. Though this was criticized for being a political move [62], close before three state elections, it meant that the Energiewende had to be accelerated, which poses practical problems for, e.g. construction of new sites and infrastructure. The main means for large-scale RE production is offshore wind in the north of the country, whereas the large industrial areas, i.e. the demand for electricity, are primarily in the south. Moreover, the original Energiewende designs included a large role for R\&D and new technology development, which cannot easily be accelerated. The 'big four' predicted blackouts following this sudden capacity reduction, but this did not actually happen and security of supply thus was ensured.
The German RE policy subsystem is moderately decentralized. Although the federal level sets policy targets and goals, the states decide about the implementation of these projects, e.g. through the allocation of wind zoning plans and subsidy schemes [35]. This is often delegated to municipalities.

The discourse in the government policy is an integration of multiple motivations. The main motivations are industrial opportunities, security of supply and the reduction of greenhouse gas emissions (personal communications PBL, 2013). This means that policies that demand short-term investments, but are profitable on the long-term, are still considered (ibid.). Moreover, German energy policy is based on ethical issues regarding the environment and anti-nuclear considerations, and this is more heavily weighted in decision making than in other European countries (ibid.). In contrast to the Dutch discourse, energy policy is part of a lively and open public debate, including, e.g. the demonstrations of 210,000 people for closure of all nuclear power plants following Fukushima [63]. The subsequent historic win of the Green Party in the Baden Württemberg state elections and the phase-out of nuclear power are attributed to a pro-renewables and anti-nuclear public opinion $[42,64]$. Both policy decisions and outcomes and the relative weight attached to environmental and safety concerns strengthen the ecological and ethical basis of the discourse as reflected in the policies.

In conclusion, we can see that the German government highly prioritizes the energy transition and that it sees an active role for decentralized projects of all kinds, including different RE sources and ownership models, which increases public acceptance [38].

\section{Community initiatives in Denmark}

The idea of a community initiative carries a somewhat different meaning in Denmark: where in the Netherlands, these initiatives often have difficulties finding a mode of cooperation with the local government, in Denmark the local government works closely together with local companies and (groups of) citizens. The system is very decentralized, which means that municipalities (Kommuner) have to realize the ambitious national goals on a local level, without much guidance or budget (personal communications Region Nordjyllland, 2013). Communities thus have a lot of opportunities to design their own projects, and the local government is likely to support them. Moreover, provision for RE is seen as a means for revitalizing the community, generating revenue, and ensuring energy security and independence.

Community initiatives in Denmark can be divided into three different types. First, there are numerous community district heating $(\mathrm{CDH})$ systems that operate local heat networks, often combined with electricity production (CHP). 
They are owned either by Kommuner or cooperatives (personal communications CDH Aalborg, 2013). Traditionally, the $\mathrm{CDH}$ plants were fuelled not only by mostly natural gas but also by waste incineration. Frederiksberg was for example the first CHP waste incineration plant, established in 1903 [65]. Today, there are hundreds of $\mathrm{CDH}$ plants, both in rural areas (e.g. the famous Samsø island) and in cities. There are, e.g. 20 systems for Copenhagen alone (ibid.), which proves that in both rural and urban regions, these projects are feasible. Only in recent years, following national RE targets, have $\mathrm{CDH}$ systems become more 'green' through using solar panels and biomass combustion. They are now fuelled by a variety of renewable resources including wood chips and biogas, and residual heat from local industrial sites is used. Natural gas is still present, but mostly as a backup (personal communications CDH Aalborg, 2013).

A second type of initiative, and one that Denmark is renowned for, is wind cooperatives. The 1970s oil crisis caused a massive rise of wind cooperatives, and estimations of the total number of locally owned turbines ran up to over 2,000 in total in the late 1990s [66]. These projects were typically small, rural and owned by farmers, private households or local companies or investors. However, following the liberalization of the energy market and the high local RE targets, many of the turbines were sold off to large investors who could replace them with bigger and more expensive turbines [67]. In 2008, a survey revealed around 100 active wind cooperatives [68], and three-quarters of the onshore turbines are still locally owned [69]. Recently, some high-profile projects have emerged, such as the renewable island Samsø and Hvide Sande Havn windfarm cooperative (personal communications Samsø development research Copenhagen University, 2013) [70]. However, these contradict the general trend in wind turbine ownership, which moves away from local projects and towards large project developers and investors (personal communications Dong Energy, 2013; personal communications Wind People Denmark, 2013). The subsidy that has been available for an environmental impact assessment for new projects was only applied for 12 times in the past few years, indicating that the number of aspiring new projects is negligible (ibid.).

A third group of projects is a more diverse category of small manure fermentation projects, solar panels for apartment buildings and projects in experimental stages, such as wave power projects (personal communications Danish Wave Energy Centre, 2013). Denmark has always been a frontrunner in developing and testing new technologies at the local level, but budget cuts have limited this since severe subsidy cuts in 2002 (personal communications Nordic Folkecenter for Renewable Energy, 2013). Leading up to the 2009 UN Climate Change Conference in Copenhagen, many local informal initiatives were started to, e.g. discuss reduction of consumption and sustainability in the local community in general. However, after the conference had ended, the interest in this topic lessened, and most of these groups dissolved (personal communications Wind People Denmark, 2013). The unique feature of these groups was that their motivation was mostly environmental: the wind cooperatives and other RE initiatives have a primarily economic motivation (personal communications Region Midtjylland, 2013; personal communications Energibyen Frederikshavn, 2013). The Kommuner support this, both to improve the local economy and to reach the national targets for RE.

Out of the 98 Kommuner in Denmark, 18 have a complete climate change policy, including measures for mitigation and adaptation to climate chang, and a plan for decentralized RE provision. Other Kommuner are in the process of developing this [71]. Most employ energy advisors, which provide local companies and households with free advice on energy savings and production. Although these initiatives are partly initiated by the Kommune government, the community plays a large role and community partners are equal to the government in terms of decision-making, planning and implementation of the activities.

\section{The Danish institutional arrangement}

Of the three countries, Denmark is the most decentralized. Municipal governments (Kommuner) have both financial means and large independence for policy design, including on RE. There is however a strong national framework in which the policies have to be embedded, and it is ambitious: Denmark strives to have $100 \%$ of its energy supply covered by RE by 2050. The 2012 Energy Agreement provides an extensive framework of energy saving and RE production measures. The motivation for the agreement is the protection of the climate. RE production is planned mostly through offshore wind and (co-)combustion of biomass, although Denmark also invests considerably in $R \& D$ for wave power.

The main actor at the central government level is the Ministry of Climate and Energy, the name already demonstrating an environmental take on the energy problem. The main partner of the Minister of Energy is the Ministry of Finance, which poses severe constraints on the RE ambitions of Denmark, as the Climate and Energy ministry does not have the funds to match its ambitious targets (personal communications Ministry of Climate and Energy, 2103; personal communications Dong Energy, 2013). The Ministry also works together with the Danish Energy Agency (DEA), an interest organization for energy producers. There is a strong lobby in the energy sector, but it focuses on favourable business models and not necessarily on fossil fuels (ibid.; personal communications GreenGo Energy, 2013). The main market parties 
in Denmark, holding the majority of the production facilities, are Dong Energy and Vattenfall. Dong Energy is strongly in favour of RE, as it owns large offshore wind parks. Its lobby is therefore focused at increase of the FIT (ibid.). Since Dong Energy is the most influential member of the DEA, this organization lobbies with the same goals. Another main actor is Maersk, which has large interests in fossil fuels. It has been quiet in the public debate on energy but defends its interests with the national government (ibid.). All in all, the fossil fuel lobby is not as prominent as in the Netherlands and Germany. Moreover, Denmark has no nuclear power facilities, and a 1985 law prohibits the production of any nuclear power. Following the 1970s oil crisis, self-sufficiency became the primary goal that was attained in 1997 [72]. A last group of actors that is influential in Denmark are turbine manufacturers, including Vestas, Siemens Windpower and a number of smaller manufacturers. These are important for regional employment and form a motive for regional and local projects to invest in wind power (personal communications Region Midtjylland, 2013).

Another token of decentralization is the Danish planning system. Following the 1997 revision of the number, size and responsibilities of the provinces (Regioner), the responsibility for spatial planning of wind parks was shifted from the Region to the municipality. This caused a huge loss of expertise and weakened the position of the Regioner. All have ambitious RE policies, but 'all we have left is the power to motivate, and that is not enough' (personal communications Region Nordjylland, 2013). The Kommuner are now primarily responsible for RE planning and attaining the national goals, but they have to do so on a limited budget and limited capacity (ibid.; personal communications Kommune Frederikshavn, 2013).

In terms of rules, there have been some shifts over the years, especially in FIT policies. In the 1980s, the wind policies were very supportive of local cooperatives, ensuring minimum prices through FITs, and 40\% investment subsidies for construction [72]. These policy measures were aimed at local communities, and the decentralized community-based approach was successful: by 1990, there were over 2,000 local cooperatives and private owners exploiting turbines (ibid.). 'wind turbines had obtained a right to sell their electricity to large power companies at fixed prices, but apart from that, the Danish electricity sector was in reality a monopoly' (ibid.). The liberalization of the energy market that was enforced by the European Union replaced this monopoly with a market-oriented system in the early 2000s. The FIT scheme was replaced by RE portfolio standards and an emissions trading scheme in an attempt to control the costs of the support for RE. Because of the limited competitiveness of wind turbines, a premium was introduced in 2003 , but a market approach remained dominant. In 2007, the government set the $100 \%$ by 2050 target, and shortly after that, the marketbased support system was transformed back to an FIT system with a clearer steering role for the state, as the market approach was found insufficient to reach such ambitious goals. FIT was reintroduced in 2009, with differentiated rates per RE source. Supplementing this, the 2012 Energy Agreement includes 62 actions for the government, ranging from feasibility analyses for certain types of projects to a new 'security of supply' tax on energy. The agreement does not only include RE production but also energy savings, heat systems and transport. For heating, the subsidy scheme for RE heating is abolished and replaced by a ban on all use of oil and natural gas in new buildings. RE sources for heating are still exempt from tax obligations. Solar panels were supported through a net taxation model, but this has been abandoned in 2012 as it became too costly. Moreover, a 'security of supply tax' was introduced on all energy, including RE, 'of course, this tax has nothing to do with security of supply. It is a way of including renewable sources in the taxation too' (personal communications Dong Energy, 2013). These late subsidy cuts and new tax schemes have made the national government an unreliable partner for local initiatives, and investments in RE, especially on solar panels, have almost come to a standstill (personal communications Wind People Denmark, 2013).

As the only country in this comparison, Denmark has a section in its energy law aimed specifically at communities. This law ensures a fund for local community development as a financial compensation for onshore wind turbine and determines that in a commercial build of new onshore turbines, $20 \%$ of shares should be offered to the local population to give them a chance to benefit financially from the revenue of the turbine [29]. These laws were put into place because after local ownership of turbines declined, there was a huge NIMBY response to new projects (personal communications Wind People Denmark, 2013; personal communications Samsø development research Copenhagen University, 2013). This was especially prominent in cities and other more densely populated areas, where NIMBY protests are more easily organized and more people are affected by visual or sound disturbances (ibid.).

Finally, an analysis of the discourse reveals a mix of economic and environmental motivations. Where the original aims are environmental protection, climate change mitigation and energy security, the policy measures are designed to stimulate competitiveness of RE and economic motivations can especially be seen at the local level (e.g. personal communications Region Midtjylland, 2013). Energy security, independence from (imported) fossil fuels and nuclear power and economic long-term profitability motivate policy plans. The public debate is focused on 'green' issues on 
the national level, but for decentralized projects, there is a mixed response. Partly, community-based projects are framed as a means of community revitalization (see below). Demographic decline and a lack of social cohesion can be changed through community projects for RE: RE is not seen as an end in itself, but as a means to a social end (e.g. personal communications Samsø development research Copenhagen University, 2013). However, where there is no revenue for the local community, NIMBY responses have increased. Ownership seems to play an important role in local acceptance, but either way, the local discourse is not as strongly environmentally oriented as the national policy discourse. Nevertheless, local communities are still investing in 'becoming green', through various means including turbine exploitation, local heat planning and privately owned solar power. The famous example of the island of Samsø shows that innovation at the local level leads to new ownership structures (a mix of cooperatively owned turbines and turbines owned by farmers) and to new opportunities for local revenue. This development takes place in cities and rural areas alike, but city-based projects tend to be more top-down and focused on convincing citizens to participate, where in rural areas, they tend to play more (personal communications Project Zero Sønderborg, 2013).

\section{Conclusions}

Community initiatives emerge across different (Western European) institutional contexts, but the characteristics of the institutional system influence their development, abundance and success. Next to differences in financial incentives, the relative positions of the state, market parties and communities and their goals and priorities are among the key factors that explain the rise and continuity of community initiatives. Below, we summarize our findings on how the institutional arrangements enable or constrain community initiatives, following the dimensions of the PAA.

\section{Institutional space for community initiatives}

Across the three countries, there are noticeable differences in the dominant policy discourse. In the Netherlands, this is a strongly economic rationale, which creates a misfit with the rising number of community initiatives that are mostly operating on the basis of environmental concerns. In Germany, the policy discourse is predominantly environmental, and the local communities act on this same rationale. This discursive coherence creates institutional support for communities. In Denmark, we see that the national government currently has a mixed environmental, social and economic discourse and that these (but primarily the economic) are recurring across government levels as well as within the local initiatives, which increases the cooperation between government and initiatives.
This demonstrates the importance of the dimension of policy discourses, not only that it reflects environmental, economic or mixed rationales but also that national discourses can align with discourses of decentralized policy levels and of local communities. This alignment creates institutional (discursive) space for community initiatives. In terms of actors and resources, we see that the market parties pro-fossil fuels and pro-nuclear power have a strong presence in the Netherlands and Germany but are less dominant or even absent in Denmark. On the contrary, over the years, Denmark developed a strong role of large market parties for RE supply and turbine manufacturing. The government is most dominant in the German system and least in the Dutch, which demonstrates that some governmental steering, especially through financial incentives, is critical for community initiatives. In Denmark, decentralization is an important feature of institutional arrangement; the Kommuner acquire relatively not only more power but also large responsibilities. There are quite some differences between these Kommuner in their ambition, goals and activities for renewable energy, but most are ambitious and set up a large range of local projects. The resources for community initiatives are best accessible in Denmark, where FITs are guaranteed and subsidies for planning are available. Germany also has FITs and a number of local and regional subsidies. In the Netherlands, the subsidy scheme is the least elaborate and consistent. We see that the most enabling environment for community initiatives is an arrangement in which policies on the resource division are consistent and where powerful actors, whether governmental or market parties, have a stake in renewable energy.

Classification into the governance ideal types provided insight in the position of communities within the subsystem. Table 2 shows the key characteristics of each system in terms of the PAA, and which ideal-typical institutional arrangement this resembles most.

We hypothesized that the Netherlands would have a market-oriented arrangement, that Germany would be strongly state-oriented and that in Denmark, communities would have a more dominant position. For the Danish case, this hypothesis has been falsified. Over the last decade, the economic rationale (including the economics of scale) has gained influence and has decreased the power of the communities in favour of state-initiated projects with large market parties. In the Netherlands and Denmark, the ideal types can indeed be recognized. The Netherlands can be categorized as a mostly economic or market-oriented policy arrangement. Policies are very often framed in terms of cost-benefit analyses, emphasizing risk avoidance rather than innovation and focusing on the (international) economic position of the country in energy supply and trade. German energy 
Table 2 Policy arrangement of the RE policy subsystem

\begin{tabular}{|c|c|c|c|}
\hline & The Netherlands & Germany & Denmark \\
\hline Actors & $\begin{array}{l}\text { Department of Economic Affairs, large } \\
\text { (fossil fuel) market parties have strong } \\
\text { influence, little decentralization }\end{array}$ & $\begin{array}{l}\text { Ministry of Economy and Technology, involvement } \\
\text { of Chancellor, large (nuclear/fossil fuel) market } \\
\text { parties have moderate influence, public opinion } \\
\text { strongly pro-RE, moderate decentralization }\end{array}$ & $\begin{array}{l}\text { Department of Energy and Climate, } \\
\text { large (pro-RE) market parties have little } \\
\text { influence, large decentralization }\end{array}$ \\
\hline \multirow[t]{2}{*}{ Rules } & \multirow{2}{*}{$\begin{array}{l}\text { Goal of } 14 \% \text { by } 2020, \text { no FIT but } \\
\text { various subsidies, rules mostly } \\
\text { regulatory }\end{array}$} & $\begin{array}{l}\text { Goal of } 35 \% \text { by } 2020 \text { and phase out of nuclear } \\
\text { power plants }\end{array}$ & \multirow{2}{*}{$\begin{array}{l}\text { Goal of } 100 \% \text { by } 2050 \text {, rules both } \\
\text { constraining and enabling, FITs } \\
\text { present }\end{array}$} \\
\hline & & Rules mostly enabling, FITs present & \\
\hline Resources & Moderate government spending & Large spending on goals Energiewende & Large spending on long-term goals \\
\hline Discourse & $\begin{array}{l}\text { Economical (short term), energy } \\
\text { security, competitive position, } \\
\text { profitability of RE }\end{array}$ & Economical (long-term) & Mixed environmental and economical \\
\hline $\begin{array}{l}\text { Ideal type } \\
\text { arrangement }\end{array}$ & Market oriented & State oriented & State oriented \\
\hline
\end{tabular}

policy is much more state-based and proactive and, besides the emphasis (and possibility) of long-term industrial politics, is also more based on ethical issues regarding the environment, climate change and anti-nuclear considerations.

This is not to say that the Danes have abandoned their decentralized sustainability politics. The Danish state shows continuous ambition in RE policies, leading to the 100\%-by-2050 target, and an ever more unambiguous steering role for the state as the market approach was deemed 'insufficient' to reach ambitious goals on its own. The Danish system is, though decentralized and having a strong role for the local authorities (Kommunerrer), also a state-oriented institutional system, with intensive cooperation between societal initiatives and governmental actors. The Danish state used to create much room for community initiatives, and one of the spin offs of its pro-RE policy is the establishment of strong RE market parties, which increase their prominence in the policy arrangement.

\section{Community initiatives}

The position, shape and approach of community initiatives vary considerably across the countries. A number of differences that stand out are listed below.

In Table 3, we see different dynamics between the countries, which can be explained by the differences in the institutional systems of each country. However, the trend across the systems is that community initiatives are rising and becoming more powerful. Even though the ownership model in Denmark is changing for wind turbines, community initiatives are not disappearing from the scene. Community initiatives are gaining influence in Germany and the Netherlands, and whether the shift to RE is approached from an economic or an environmental perspective, and taken slow or fast, communities seem to be a key ingredient in the new RE mix. In the 'Methods' section, it was stressed that the ideal type of a community-oriented arrangement does not stand on its own (though ideal types never do) but needs to be supported by the state and market. In none of the case study countries, the community orientation is dominant, but in Germany and Denmark, a combination seems to be possible of both of top-down implementation of ambitious environmental targets and local facilitation and innovation, thus creating more institutional space for community initiatives. This increases the fertile ground for communities to (co-)develop projects and thus steers the energy sector towards a more heterogeneous mix of initiatives at the local level.

The policy arrangements in the three countries vary considerably, which can be reconstructed by looking at

Table 3 Differences community initiatives movements across countries

\begin{tabular}{|c|c|c|c|}
\hline & The Netherlands & Germany & Denmark \\
\hline $\begin{array}{l}\text { Phase of } \\
\text { development of } \\
\text { initiatives }\end{array}$ & $\begin{array}{l}\text { Early phase of development, minority } \\
\text { well-established and fully operational }\end{array}$ & $\begin{array}{l}\text { Well-established and } \\
\text { operational, searching new } \\
\text { modes }\end{array}$ & Well-established and operational \\
\hline $\begin{array}{l}\text { Size and growth of } \\
\text { number of initiatives }\end{array}$ & Moderate group, growing rapidly & Moderate group, growing & $\begin{array}{l}\text { Large group, decline traditional cooperatives, } \\
\text { growth new local initiatives }\end{array}$ \\
\hline Focus activity & $\begin{array}{l}\text { RE provision, support for private savings/ } \\
\text { production }\end{array}$ & $\begin{array}{l}\text { Collective production, energy } \\
\text { savings }\end{array}$ & Collective production, creating revenue \\
\hline Momentum & $\begin{array}{l}\text { Little public debate on energy but relatively } \\
\text { large attention for community initiatives }\end{array}$ & $\begin{array}{l}\text { Large public debate on } \\
\text { nuclear power and green } \\
\text { economy }\end{array}$ & $\begin{array}{l}\text { Large public consensus over 'green' goals and } \\
\text { economic possibilities RE, increasing NIMBY } \\
\text { response }\end{array}$ \\
\hline
\end{tabular}


the conditions external to the policy subsystem and a series of policy responses to these conditions. Examples are the economic crisis that forced Denmark to focus on renewable energy but also on the economic most viable options (large scale investments), the biophysical conditions in the Netherlands that explain a focus on fossil fuels and the anti-nuclear sentiments in combination with the shock of the 2011 Fukushima disaster that sped up the phasing out of nuclear power in Germany. This interplay between external conditions, policy and political decisions and dynamics between the actors in the policy subsystem are indirectly - by way of changing arrangements - determining the institutional space for communities.

Our findings suggest that, for the institutional space for community initiatives, the precise content of the dominant discourse seems less determining than the alignment of a dominant discourse across government levels and actors. If the community has a rationale similar to the government, this creates opportunities for community initiatives. Moreover, the division of resources and the rules of the game determine the availability of funding, permits, etc., but their precise content seems less important than their stability and predictability and how they are in line with the needs of the communities.

However, these conclusions do not imply that structural characteristics are more important for success than agency or biophysical characteristics. Although international variation can be explained through different national institutional arrangements, all interviews pointed out that for individual projects, agency characteristics such as leadership skills, pro-environmental attitudes and management skills play a vital role. Moreover, the possibilities and planning processes for projects depend on the (bio)physical conditions, such as the degree of urbanization. In the past, most projects were realized in rural regions, but the increasing variety of projects has led to more project designs appropriate for built environments, and projects became more equally distributed between cities and rural areas. Although this is the case for small projects, national governments still tend to focus on large rural and offshore projects.

This research has sketched three national arrangements and the position of the community movement therein. This broad scope gives an overview of national dynamics and trends, but more detailed studies of cases of sustainable regions, cities and initiatives could provide more insight in the dynamics between the involved actors and policies. This could strengthen and nuance the analysis of this article. Moreover, there remains a need for a comprehensive overview of community initiatives. The lack of reliable data on the number and activities of community initiatives poses a constraint for this analysis, and further research will increase the validity of the findings and provide more insight into a category of actors that is diverse, rapidly growing and increasingly important for RE provision.

\section{Abbreviations}

CDH: community district heating; CHP: combined heat and power; DEA: Danish Energy Agency; FIT: feed-in tariff; NGO: non-governmental organization; NIMBY: not in my back-yard; PAA: policy arrangements approach; R\&D: research and development; RE: renewable energy; SDE+ Stimuleringsregeling Duurzame Energie; SER: Sociaal Economische Raad; UN: United Nations.

\section{Competing interests}

The authors declare that they have no competing interests.

\section{Authors' contributions}

$\mathrm{MO}$ has gathered the data and prepared the concept version. MW and JH have provided the theoretical approach and designed the research. The authors have jointly drafted and revised the manuscript. All authors read and approved the final manuscript.

\section{Authors' information}

Marieke Oteman is a PhD student at the Institute for Management Research, focusing her research on community initiatives for renewable energy. She is part of the Department of Geography, Planning and Environment. Mark Wiering is an Associate Professor in Political Sciences of the Environment at the Department Geography, Planning and Environment of the Nijmegen School of Management. Jan Kees Helderman is an Associate Professor in Public Administration at the Department Political Sciences and Public Administration of the Nijmegen School of Management.

\section{Acknowledgements}

The authors would like to thank the two anonymous reviewers for their helpful comments and suggestions.

Received: 12 September 2013 Accepted: 18 March 2014 Published: 19 May 2014

\section{References}

1. European Parliament and Council (2009) Directive 2009/28/EC. Off J Eur Union, Brussels

2. Renewable Energy Sources COOPeratives (REScoop) (2013). Energy transition. http://rescoop.eu Accessed 4 May 2013

3. Trouw (2013) Duurzame Top 100, de volledige lijst. Newspaper Article Dagblad Trouw. 09/10/2013

4. Dagbladet Information (2013) Kampagnen "Hvad gør vi nu? - vores omstilling til et bæredygtigt samfund". http://www.voresomstilling.dk Accessed 2 September 2013

5. Walker G (2008) What are the barriers and incentives for community-owned means of energy production and use? Energy Policy 36(12):4401-4405

6. Middlemiss L, Parrish B (2010) Building capacity for low-carbon communities: the role of grassroots initiatives. Energy Policy 38(12):7559-7566

7. Walker G, Devine-Wright P (2007) Community renewable energy: what should it mean? Energy Policy 36:497-500

8. Rogers J, Simmons E, Convery I, Weatherall A (2008) Public perceptions of opportunities for community-based renewable energy projects. Energy Policy 36:4217-4226

9. Peters $M$, Fudge $S$, Sinclair $P$ (2010) Mobilizing community action towards a low-carbon future: opportunities and challenges for local government in the UK. Energy Policy 38:7596-7603

10. Ediger V, Akar S, Uğurlu B (2006) Forecasting production of fossil fuel sources in Turkey using a comparative regression and ARIMA model. Energy Policy 34(18):3836-3846

11. Illich I (1978) Toward a history of needs. Pantheon Books, New York

12. Beck U (1992) Risk society: towards a new modernity (Vol. 17). Sage Publishers, London

13. Lazo J, McClain KT (1996) Community perceptions, environmental impacts, and energy policy: rail shipment of coal. Energy Policy 24(6):531-540

14. Robbins C, Rowe J (2002) Unresolved responsibilities: exploring local democratisation and sustainable development through a community-based waste reduction initiative. Local Gov Stud 28(1):37-58 
15. Shaw S, Mazzucchelli P (2008) Evaluating the perspectives for hydrogen energy uptake in communities: success criteria and their application. Energy Policy 38:5359-5371

16. Schut M, Van Paassen A, Leeuwis C, Bos S, Leonardo W, Lerner A (2011) Space for innovation for sustainable community-based biofuel production and use: lessons learned for policy from Nhambita community, Mozambique. Energy Policy 39:5116-5128

17. Bulkeley H, Betsill M (2005) Rethinking sustainable cities: multilevel governance and the 'urban' politics of climate change. Environ Polit 14(1):42-63

18. Bergmann A, Colombo S, Hanley N (2008) Rural versus urban preferences for renewable energy developments. Ecol Econ 65(3):616-625

19. Hall P, Taylor R (2006) Political science and the three new institutionalisms. Polit Stud XLIV:936-957

20. Sabatier P, Jenkins-Smith H (1993) Policy change and learning: an advocacy coalition approach. Westview Press, Boulder

21. Howlett M, Ramesh M (2003) Studying public policy cycles and policy subsystems, 3rd edition. Oxford University Press, Oxford

22. Streeck W, Schmitter P (1985) Community, market, state, and associations? The prospective contribution of interest governance to social order. Eur Sociol Rev 1(2):119-138

23. Helderman J-K (2007) Bringing the market back in? Institutional complementarity and hierarchy in Dutch housing and health care. Erasmus University, Rotterdam

24. Baccaro $L$ (2005) Civil society meets the state: towards associational democracy? Soc Econ Rev 4:185-208

25. Arts B, Leroy $P$ (ed) (2006) Institutional dynamics in environmental governance. Springer, Dordrecht

26. Wiering M, Arts B (2006) Discursive shifts in Dutch river management: 'deep' institutional change or adaptation strategy? Hydrobiologia 565:327-338

27. Toke D (2002) Wind power in UK and Denmark: can rational choice help explain different outcomes? Environ Polit 11(4):83-100

28. Arts B, Van Tatenhove J (2000) Environmental policy arrangements: a new concept. In: Goverde H (ed) Global and European Polity. Impacts for Organisations and Policies. Ashgate, Aldershot, pp 223-238

29. Klima- of Energieministerit (2008) Lov om Fremme af Vedvarende Energi LOV 1392 af 29/12/2008 Copenhagen

30. Altheide D (1996) Qualitative Media Analysis. Sage, London

31. Bozsoki I (2013) Legal sources on renewable energy: Germany policies. http://www.res-legal.eu Accessed 1 May 2013

32. HIER Opgewekt Klimaatcampagne (2013) Inventarisatie Lokale Energie Initiatieven. http://www.hieropgewekt.nl Accessed 3 May 2013

33. E-Decentraal (2013) Ledenoverzicht E-decentraal. http://www.e-decentraal. com Accessed 3 May 2013

34. Jobert A, Laborgne P, Mimler S (2007) Local acceptance of wind energy: factors of success identified in French and German case studies. Energy Policy 35(5):2751-2760

35. Lipp J (2007) Lessons for effective renewable electricity policy from Denmark, Germany and the United Kingdom. Energy Policy 35(11):5481-5495

36. Schreuer A, Weismeier-Sammer D (2010) Energy cooperatives and local ownership in the field of renewable energy technologies: a literature review. Research Reports / RICC, 4. WU Vienna University of Economics and Business, Vienna

37. Toke D, Breukers S, Wolsink M (2008) Wind power deployment outcomes: how can we account for the differences? Renew Sustain Energy Rev 12 (4):1129-1147

38. Musall FD, Kuik O (2011) Local acceptance of renewable energy - a case study from southeast Germany. Energy Policy 39(6):3252-3260

39. Termaat $L$ (2013) Waait de wind harder in Duitsland? Een onderzoek naar de lokale sociale acceptatie van windparken in Nederland en Duitsland Masters Thesis Radboud University Nijmegen, Nijmegen School of Management, Nijmegen

40. Boontje P (2013) A German wind and solar energy cooperatives business model research. Masters Thesis, Delft University, Management of Technology

41. Schreuer A (2012) Energy cooperatives and local ownership in the field of renewable energy. Country cases Austria and Germany. RICC Research Report 2012/02, Vienna

42. Heinrich Böll Stiftung (2013) Energy transition - the German Energiewende http://energytransition.de Accessed 25 April 2013
43. Agterbosch S (2006) Empowering wind power; on social and institutional conditions affecting the performance of entrepreneurs in the wind power supply market in the Netherlands. Netherlands Geographical Studies, Utrecht

44. Wieg A, Vesshoff J, Boenigk N, Dannemann B, Thiem C (2013) Energy cooperatives - citizens, communities and local economy in good company. DGRV, Berlin

45. Van der Loo F (2013) Op Reis naar het Zuiden - Energietransitie 2000-2010. Maurits Groen Milieu \& Communicatie, Haarlem

46. Centraal Bureau voor de Statistiek (CBS) (2011) Zonder subsidie is windenergie nog niet rendabel. CBS Webmagazine. November 2011 http://www.cbs.nl Accessed 8 May 2013

47. Agentschap NL (2013) Energiesubsidiewijzer: de wegwijzer voor energiebesparing. http://www.energiesubsidiewijzer.nl Accessed 2 May 2013

48. Heilbron B, Mommers J, Muntz T, De Zeeuw H (2013) Nog een Eeuw Fossiel - Onderzoeksdossier het Land van Gas en Kolen. Journal De Groene Amsterdammer, 136:4

49. Centraal Bureau voor de Statistiek (CBS) (2012) Industrie en Energie Jaarcijfers. http://www.cbs.nl

50. Ecofys (2011) Overheidsingrepen in de Energiemarkt - Onderzoek naar het Nederlandse speelveld voor fossiele, duurzame en kernenergie. Ecofys Publications, Utrecht

51. Delta (2012) Voorlopig Geen Tweede Kerncentrale in Borssele Delta Nieuwsarchief. http://www.delta.nl

52. Staab J (2013) Erneuerbare Energien in Kommunen. Springer Gabler, Wiesbaden

53. Flieger B, Klemisch $H$ (2008) Eine andere Energiewirtschaft ist möglich-Pionierfunktion neuer Energiegenossenschaften. Contraste 285:105-110

54. Holstenkamp L, Ulbrich S (2010) Bürgerbeteiligung mittels Fotovoltaikgenossenschaften Arbeitspapierreihe Wirtschaft \& Recht No. 8 Leuphana Universität, Lüneburg

55. Byzio A, Heine H, Mautz R, Rosenbaum W (2002) Zwischen Solidarhandeln und Marktorientierung. Ökologische Innovation in selbstorganisierten Projekten - autofreies Wohnen, Car Sharing und Windenergienutzung. Soziologisches Forschungsinstitut der Georg-August-Universität, Göttingen

56. Degenhart H, Holstenkamp L (2013) Energiegenossenschaften als Bürgerbeteiligungen. Kommunalwirtschaft, (Sonderausgabe Oktober), pp 76-79

57. Trendresearch (2011) Marktakteure Erneuerbare Energien Anlagen in der Stromerzeugung. Klaus Novy Institut. http://www.kni.de Accessed 12 May 2013

58. Association of Energy Engineers (AEE) (2011) AEE Survey of the Energy Industry 2012. http://www.aeecenter.org Accessed 15 May 2013

59. Buchan D (2012) The Energiewende-Germany's Gamble. Oxford Institute for Energy Studies. http://www.oxfordenergy.org Accessed 27 April 2013

60. Bundesverband der Energie- und Wasserwirtschaft (BDEW) (2012) Erneuerbare Energien. http://www.bdew.de Accessed 27 April 2013

61. Noteboom J (2013) Politieke lessen uit de Duitse Energiewende PVS 2013-1050. Planbureau voor de Leefomgeving, Den Haag

62. Die Zeit (2011) Merkel gibt die Konsenskanzlerin. Die Kanzlerin nennt den Atomausstieg im Bundestag einde 'Herkulesaufgabe' für die ganze Nation. SPD-Fraktionschef Steinmeier spricht von falschem Pathos. 09/07/2011 http://www.diezeit.de

63. Die Welt (2011) Zehntausende in Berlin bei Anti-AKW-Demo. 26/03/2011 http://www.welt.de

64. CNN (2011) Big Losses for Merkel in German State Elections CNN. 28/03/ 2011 http://www.cnn.com Accessed 10 May 2013

65. Danish Board of District Heating (2013) DHC in Denmark. http://www.dbdh. dk Accessed 18 May 2013

66. Gipe P (1996) Community-Owned Wind Development in Germany, Denmark, and the Netherlands. Wind Works. http://www.wind-works.org Accessed 18 May 2013

67. Kruse J (2006) The End of One Danish Windmill. Cooperative Politiken 09/02/2006

68. Stenkjaer N (2008) Wind Turbine Co-ops in Denmark Nordic Folkecenter for Renewable Energy. http://www.folkecenter.net Accessed 17 May 2013

69. Leidreiter A (2013) Local Development through Community Led Renewable Energy Renewable Energy World 03/04/2013. http://www.renewableenergyworld com Accessed 3 May 2013 
70. Woo F (2012) Local Communities Invest in Danish Wind Energy European Wind Energy Association. http://www.ewea.org Accessed 18 May 2013

71. LGDK (2013) Danish Local Climate Map. http://kl.dk/eu/Denmark Accessed 18 May 2013

72. Danish Energy Agency (DEA) (2012) Danish Energy Policy Report. DEA Publications, Copenhagen

doi:10.1186/2192-0567-4-11

Cite this article as: Oteman et al:: The institutional space of community initiatives for renewable energy: a comparative case study of the Netherlands, Germany and Denmark. Energy, Sustainability and Society 2014 4:11.

Submit your manuscript to a SpringerOpen ${ }^{\circ}$ journal and benefit from:

- Convenient online submission

- Rigorous peer review

- Immediate publication on acceptance

- Open access: articles freely available online

- High visibility within the field

- Retaining the copyright to your article

Submit your next manuscript at $>$ springeropen.com 